(c) American Dairy Science Association, 2005.

\title{
Association Between Live Body Weight and Milk Urea Concentration in Holstein Cows
}

\author{
D. Hojman, ${ }^{1}$ M. Gips, ${ }^{2}$ and E. Ezra ${ }^{3}$ \\ ${ }^{1}$ Dairy Cattle Department-Extension Service, \\ Ministry of Agriculture and Rural Development, \\ Bet Dagan 50150, Israel \\ ${ }^{2}$ Central Milk Laboratory, and \\ ${ }^{3}$ Herdbook Data Center, Israel Cattle Breeders' Association, \\ Caesaria Industrial Park, Israel
}

\section{ABSTRACT}

Use of milk urea (MU) concentration as a parameter for detection of nutritional imbalances requires identification and quantification of nutritional and nonnutritional factors that influence it. The objective of this study was to assess the relationship between live body weight (BW) and MU concentration in Holstein cows. Results for the test-day measurements at 7 dairy farms were obtained from the Israeli Dairy Herd Improvement Center and concomitant cow weights were registered in local computerized weighing systems. A total of 1996 cows and 25,485 records were studied. The overall unadjusted per-cow mean MU nitrogen concentration and $\mathrm{BW}$ were $15.3 \mathrm{mg} / \mathrm{dL}(\mathrm{SD}=3.8)$ and $593 \mathrm{~kg}(\mathrm{SD}=$ 84), respectively. The linear association between BW and MU was negative and highly significant and the quadratic component of BW had a highly significant positive association with MU. There was a significant interaction between the association of MU and BW with lactation number. Sampling month, milk yield, milk fat percentage, and somatic cell count accounted for significant variation in MU. Predicted MU concentrations at different BW values were calculated for each parity group, by setting equations that included the estimates of the variables associated with MU and constant values (lactation averages) for the independent variables, with the exception of BW. Plotting of results showed exponential characteristics for the relationship between BW and predicted MU concentrations. At any of the considered BW, predicted MU concentrations were lower for first-parity cows. The trends and interactions found in the present study may contribute to improving accuracy of models designed to calculate urinary nitrogen excretion rates and normative milk urea concentrations.

Received July 3, 2004.

Accepted October 8, 2004.

Corresponding author: Daniel Hojman; e-mail: danhoj@shaham. moag.gov.il.
(Key words: milk urea, body weight, urinary nitrogen)

Abbreviation key: $\mathbf{M U}=$ milk urea, $\mathbf{U N}=$ urinary nitrogen.

\section{INTRODUCTION}

Milk urea (MU) is highly correlated with serum urea (Butler et al., 1996; Broderick and Clayton, 1997) and with urinary nitrogen (UN) excretion (Jonker et al., 1998). Its concentration represents mainly $(r=0.86)$ $\mathrm{N}$ losses from rumen fermentation (Hof et al., 1997). Therefore, MU can be used to monitor nutritional imbalances in dietary protein, and thus increase production efficiency and reduce avoidable mineral output to the environment. Use of MU measurements for these purposes requires the identification and quantification of the nutritional and nonnutritional factors that influence it.

Nutrient composition variables that have major effects on MU concentration are dietary CP, RDP, RUP, energy, energy to protein ratio, nonstructural carbohydrates, and NDF (Broderick and Clayton, 1997; Godden et al., 2001; Hojman et al., 2004). Managerial and production factors associated with MU concentration are milk yield, and fat and protein contents (Godden et al., 2001; Rajala-Schultz and Saville, 2003; Hojman et al., 2004), SCC (Hojman et al., 2004), parity (Butler et al., 1995; Carlsson et al., 1995; Broderick and Clayton, 1997), DIM (Carlsson et al., 1995; Hojman et al., 2004), month of the year (Hojman et al., 2004), breed (Rodriguez et al., 1997; Johnson and Young, 2003), and live BW.

Few published studies have examined the effect of BW on MU concentration in dairy cattle. Oltner et al. (1985) reported a negative correlation between the variables. Jonker et al. $(1998,1999)$ developed a model that also accounted for a negative effect of BW on MU. In contrast, Broderick and Clayton (1997) detected a positive relationship between BW and MU concentration. Although previous research is scarce and studies have 
been based on a small numbers of cows, BW has been included in equations to predict UN excretion rates and to set normative MU concentrations for dairy cows fed according to NRC standards (Jonker et al., 1999; Kauffman and St-Pierre, 2001; Kohn et al., 2002).

The objective of this study was to evaluate the relationship between BW and MU in high-yielding Holstein cows using field data.

\section{MATERIALS AND METHODS}

\section{Data}

Records were obtained from 7 herds (Israeli Holstein breed) enrolled in the Israeli Dairy Herd Improvement system. Managerial and nutritional practices were similar across farms: cows were kept in open-shaded barns (12 to $20 \mathrm{~m}^{2} / \mathrm{cow}$ ) and fed a TMR one or more times daily. Rations were formulated using linear programs, in accordance to NRC (1989) recommendations, and usually included more than 15 ingredients. The farms were equipped with a walk-along weighing system (S.A.E., Afikim, Israel) linked to a local computer. Cows carried an electronic identification device and were weighed at 2 of the 3 daily milkings, when returning from the milking parlor to the barns. Weight data (in $\mathrm{kg}$ ) were collected, translated into daily averages, and stored in the system's memory. Milk recording was performed once a month and milk samples were analyzed at the Central Milk Laboratory, linked to the DHI Center, for milk percentages of fat, total protein and lactose, SCC, and MU concentration (Milkoscan 4000 and Milkoscan FTIR 6000 milk analyzer, Foss Electric, Hillerød, Denmark).

Results for the test-day measurements performed between January 2001 and June 2003 were received from the DHI Center, and daily average BW of the cows on those days were obtained from the computerized systems at the farms. Laboratory results for MU, percentages of fat and total protein, and SCC were combined with the corresponding daily milk yields, parity, and calving date, and with the BW records.

\section{Statistical Analysis}

Several mixed effects regression models were constructed and evaluated using Proc Mixed (SAS Institute, 1999). The outcome of interest was the individual cows' test-day MU concentrations. The considered explanatory variables were herd, cow, parity, test-day month, test-day BW, test-day milk production, and milk fat and total protein percentage, and SCC. Cow within herd and within parity was included in the random statement to control for repeated measures within a herd on different test days, and at different lactations.
Body weight was considered a covariate and a quadratic term was defined for the variable.

The statistical model developed for the initial evaluation of the association between explanatory variables and MU concentration was:

$$
\begin{gathered}
\mathrm{Y}_{\mathrm{ijklm}}=\mu+\mathrm{H}_{\mathrm{i}}+\mathrm{L}_{\mathrm{k}}+\mathrm{C}(\mathrm{H} \times \mathrm{L})_{\mathrm{jik}}+\mathrm{MD}_{\mathrm{l}}+\mathrm{DIM}_{\mathrm{ijkl}} \\
+\mathrm{DIM}_{\mathrm{ijkl}} \times \mathrm{DIM}_{\mathrm{ijkl}}+\mathrm{BW}_{\mathrm{ijkl}}+\mathrm{BW}_{\mathrm{ijkl}} \times \mathrm{BW}_{\mathrm{ijkl}} \\
+\mathrm{BW}_{\mathrm{ijkl}} \times \mathrm{L}_{\mathrm{k}}+\mathrm{BW}_{\mathrm{ijkl}} \times \mathrm{BW}_{\mathrm{ijkl}} \times \mathrm{L}_{\mathrm{k}}+\mathrm{M}_{\mathrm{ijkl}}+\mathrm{PF}_{\mathrm{ijkl}} \\
+\mathrm{PP}_{\mathrm{ijkl}}+\mathrm{SCC}_{\mathrm{ijkl}}+\mathrm{e}_{\mathrm{ijkl}}
\end{gathered}
$$

where $\mathrm{Y}_{\mathrm{ijklm}}=$ MUN, $\mu$ = overall mean, $\mathrm{H}_{\mathrm{i}}=$ herd, $\mathrm{i}=$ 1 to7, $\mathrm{L}_{\mathrm{k}}=$ parity, $\mathrm{k}=1,2,3$, and $>3, \mathrm{C}(\mathrm{H} * \mathrm{~L})_{\mathrm{ikj}}=\mathrm{cow}_{\mathrm{j}}$ within herd $\mathrm{i}_{\mathrm{i}}$ and within parity, $\mathrm{MD}_{\mathrm{l}}=$ test-day month, $\mathrm{l}=1$ to $12, \mathrm{DIM}_{\mathrm{ijkl}}=\mathrm{DIM}, \mathrm{BW}_{\mathrm{ijkl}}=$ test-day BW, $\mathrm{M}_{\mathrm{ijkl}}=$ test-day kilograms of milk, $\mathrm{PF}_{\mathrm{ijkl}}=$ test-day fat percentage, $\mathrm{PP}_{\mathrm{ijkl}}=$ test-day protein percentage, $\mathrm{SCC}_{\mathrm{ijkl}}=$ testday $\mathrm{SCC}$, and $\mathrm{e}_{\mathrm{ijklm}}=$ random residual.

Nonsignificant $(P>0.05)$ variables were subsequently removed by a backtracking elimination process. The effects that were excluded from the final model were DIM, the interaction term of $\mathrm{BW} \times \mathrm{BW}$ with parity, and test-day protein percentage. Adequacy of the models was evaluated by examining the total residual variance.

The final model was:

$$
\begin{gathered}
\mathrm{Y}_{\mathrm{ijklm}}=\mu+\mathrm{H}_{\mathrm{i}}+\mathrm{L}_{\mathrm{k}}+\mathrm{C}(\mathrm{H} \times \mathrm{L})_{\mathrm{jik}}+\mathrm{MD}_{\mathrm{l}}+\mathrm{BW}_{\mathrm{ijkl}} \\
+\mathrm{BW}_{\mathrm{ijkl}} \times \mathrm{BW}_{\mathrm{ijkl}}+\mathrm{BW}_{\mathrm{ijkl}} \times \mathrm{L}_{\mathrm{k}}+\mathrm{M}_{\mathrm{ijkl}} \\
+\mathrm{PF}_{\mathrm{ijkl}}+\mathrm{SCC}_{\mathrm{ijkl}}+\mathrm{e}_{\mathrm{ijklm}}
\end{gathered}
$$

with symbols used as defined above.

To assess overall model fit, the GLM procedure of SAS (SAS Institute, 1999) was used to test a model that was similar to model [2] examined by the Proc Mixed procedure. The resultant value of $\mathrm{R}^{2}$ is reported here.

Expected MU concentrations (mg of MUN/dL) at different BW were calculated for each parity group, by setting equations that included the regression estimates of the variables associated with MU and constant values for the independent variables, with the exception of BW.

\section{RESULTS AND DISCUSSION}

Milk urea concentrations are presented as MUN (mg/ dL). A total of 1996 cows and 25,485 records were registered, averaging 12.8 records per cow, across lactations. The overall unadjusted mean MUN concentration and BW at cow level were $15.3 \mathrm{mg} / \mathrm{dL}(\mathrm{SD}=3.8)$ and 593 $\mathrm{kg}(\mathrm{SD}=84)$, respectively. Average results for milk, fat, and total protein percentages, MU concentration, SCC, BW, and DIM are presented in Table 1. Average BW was 538, 591, 634, and $653 \mathrm{~kg}$ for first-, second-, third-, 
Table 1. Milk yield, fat and total protein percentages, SCC, milk urea concentration (MUN), BW, and DIM, per lactation number.

\begin{tabular}{|c|c|c|c|c|c|c|c|c|c|c|c|c|c|c|c|}
\hline \multirow[b]{2}{*}{ Parity } & \multirow[b]{2}{*}{$\mathrm{n}$} & \multicolumn{2}{|c|}{$\begin{array}{c}\text { Milk } \\
(\mathrm{kg})\end{array}$} & \multicolumn{2}{|c|}{$\begin{array}{c}\text { Fat } \\
(\% / \mathrm{kg})\end{array}$} & \multicolumn{2}{|c|}{$\begin{array}{l}\text { Total protein } \\
(\% / \mathrm{kg})\end{array}$} & \multicolumn{2}{|c|}{$\begin{array}{c}\text { SCC } \\
(\times 1000 / \mathrm{mL})\end{array}$} & \multicolumn{2}{|c|}{$\begin{array}{c}\text { MUN } \\
(\mathrm{mg} / \mathrm{dL})\end{array}$} & \multicolumn{2}{|c|}{$\begin{array}{l}\text { BW } \\
(\mathrm{kg})\end{array}$} & \multicolumn{2}{|c|}{$\begin{array}{c}\text { DIM } \\
(d)\end{array}$} \\
\hline & & Mean & SD & Mean & SD & Mean & $\mathrm{SD}$ & Mean & SD & Mean & SD & Mean & $\mathrm{SD}$ & Mean & SD \\
\hline Lactation 2 & 6945 & 36.8 & 8.1 & 3.60 & 0.56 & 3.13 & 0.30 & 258 & 657 & 15.5 & 3.6 & 591 & 70 & 148 & 83 \\
\hline Lactation 3 & 4559 & 39.0 & 9.4 & 3.59 & 0.58 & 3.09 & 0.29 & 317 & 814 & 15.2 & 3.8 & 634 & 76 & 145 & 82 \\
\hline Lactation $>3$ & 5071 & 39.6 & 9.9 & 3.54 & 0.60 & 3.03 & 0.30 & 470 & 1115 & 14.8 & 3.8 & 653 & 75 & 141 & 82 \\
\hline
\end{tabular}

and $>$ third-lactation cows, respectively. Days in milk values were longer ( $151 \mathrm{~d}$ ) for first-lactation cows than for adults. Because first-lactation cows are usually given a longer voluntary waiting period, they generally have more extended lactations.

The variables associated with MU concentration were: herd, test-day month, parity, milk yield, milk fat percentage, SCC, BW, BW $\times \mathrm{BW}(P<0.001)$, and BW $\times$ parity $(P<0.03)$. The coefficient of determination $\left(\mathrm{R}^{2}\right)$ for the GLM procedure that examined the relationship between the variables included in model [2] and MU was 0.47 .

Positive relationships were found (Table 2) between MU concentration and milk yield and milk fat percentage; the relationship between SCC and MU was negative. Milk urea concentration was significantly associated with month of the year; it was higher during the spring and at the beginning of the summer, and lower in the cold season. Those results are in good agreement with a previous study (Hojman et al., 2004) using a different data set, which analyzed variables influencing MU concentrations in Israeli dairy herds.

A significant $(P<0.001)$ relationship was found between lactation number and MU concentration. Firstlactation cows had lower MU concentrations than adult cows. Similar results have been reported in several other studies (Godden et al., 2001; Johnson and Young, 2003; Hojman et al., 2004).

The linear association between BW and MU was negative $(P<0.001)$ and the quadratic effect of BW was significant $(P<0.001)$ and positive. A significant interaction $(P<0.03)$ was found for the association of BW and MU with lactation number, meaning that the relationship between BW and MU presents dissimilar characteristics in different lactations.

No association was found between DIM and MU concentration, in contrast to previous reports (Johnson and Young, 2003; Rajala-Schultz and Saville, 2003; Hojman et al., 2004) that found a positive association between these variables and stated that MU is lowest immediately after calving, increases to a maximum concentration between 3 and 6 mo of lactation, and then slowly declines. This discrepancy between our study and previous findings might be explained by the fact that we were able to control for the association between BW and MU concentration. Body weight usually decreases after calving, reaches its lowest value at approximately 60 DIM, and then gradually recovers (Coffey et al., 2003). Interestingly, the changes in BW and MU values follow similar patterns throughout lactation. In this study, the association between BW and MU was highly significant and there was no association between DIM and MU. Previous studies did not consider this potentially confounding relationship between BW and DIM, with MU concentration.

Table 2. Effects and significance of a mixed effects model [2] describing the relationship between cow-level MUN concentration $(\mathrm{mg} / \mathrm{dL})$ and production variables, live body weight (BW), parity, month of test day, and interactions between BW and parity.

\begin{tabular}{|c|c|c|c|}
\hline Effect & Estimate & $\begin{array}{l}\text { SE of } \\
\text { estimate }\end{array}$ & $P$ value $^{1}$ \\
\hline Intercept & 20.234 & 1.259 & 0.0001 \\
\hline Milk yield ( $\mathrm{kg} / \mathrm{cow}$ per $\mathrm{d}$ ) & 0.033 & 0.0034 & 0.0001 \\
\hline Milk fat $(\% / \mathrm{kg})$ & 0.816 & 0.039 & 0.0001 \\
\hline $\mathrm{SCC}(\times 1000) / \mathrm{mL}$ & -0.0005 & 0.00003 & 0.0001 \\
\hline BW & -0.0366 & 0.0037 & 0.0001 \\
\hline $\mathrm{BW} \times \mathrm{BW}$ & 0.00003 & 0.000003 & 0.0001 \\
\hline \multicolumn{4}{|l|}{ Parity } \\
\hline Lactation 1 & -0.596 & 0.715 & NS \\
\hline Lactation 2 & 1.151 & 0.683 & NS \\
\hline Lactation 3 & 1.924 & 0.724 & 0.01 \\
\hline Lactation $>3$ & 0 & $\ldots$ & $\cdots$ \\
\hline \multicolumn{4}{|l|}{ Month of test day } \\
\hline January & 0.21 & 0.08 & 0.005 \\
\hline February & 0.68 & 0.08 & 0.0001 \\
\hline March & 1.14 & 0.08 & 0.0001 \\
\hline April & 2.74 & 0.09 & 0.0001 \\
\hline May & 2.30 & 0.09 & 0.0001 \\
\hline June & 4.09 & 0.09 & 0.0001 \\
\hline July & 2.46 & 0.10 & 0.0001 \\
\hline August & 0.66 & 0.11 & 0.0001 \\
\hline September & 1.42 & 0.10 & 0.0001 \\
\hline October & -1.31 & 0.10 & 0.0001 \\
\hline November & 0.81 & 0.09 & 0.0001 \\
\hline December & 0 & $\ldots$ & $\ldots$ \\
\hline \multicolumn{4}{|l|}{ BW $\times$ Parity } \\
\hline $\mathrm{BW} \times$ Lactation 1 & 0.000818 & 0.0012 & NS \\
\hline BW $\times$ Lactation 2 & -0.00086 & 0.0011 & NS \\
\hline BW $\times$ Lactation 3 & -0.00249 & 0.0011 & 0.03 \\
\hline $\mathrm{BW} \times$ Lactation $>3$ & 0 & $\ldots$ & $\ldots$ \\
\hline
\end{tabular}

${ }^{1} P$ of Student's $t$ value for regression estimates. 


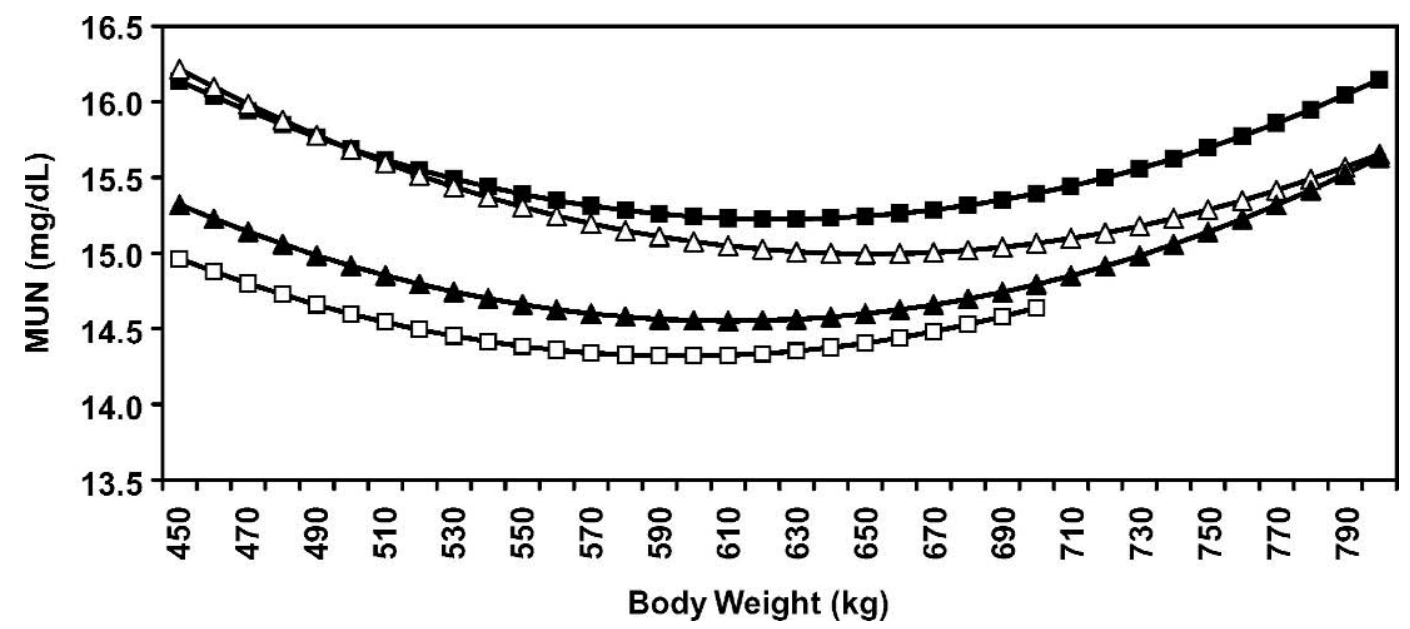

Figure 1. Predicted milk urea (MU) concentrations calculated for different body weight (kg) values for lactations $1(\square), 2(\square), 3(\triangle)$, and $>3(\boldsymbol{\Lambda})$, using estimates of variables that were significantly associated with MU and constant average values of the independent variables in the mixed effects model.

Expected MU concentrations at different BW were calculated for each parity group using equations that included estimates of the variables associated with MU (Table 2) and constant values (lactation averages, Table 1) for the independent variables, with the exception of BW. Regression estimates of "herd" and "test-day month" on MU were averaged ( 0.212 and 1.266 , respectively) and included in the equations. Calculations of predicted MU were performed for a range of $\mathrm{BW}$ values, from 450 to $700 \mathrm{~kg}$ for first-parity cows, and up to 800 $\mathrm{kg}$ for adult cows, in 10-kg increments. Results are presented in Figure 1 and Table 3.

Oltner et al. (1985) and Jonker et al. (1998, 1999) reported a negative association between $\mathrm{BW}$ and $\mathrm{MU}$ concentration. Kohn et al. (2002) reevaluated calculations of Jonker et al. (1998, 1999) and Kauffman and St-Pierre (2001) and estimated the relationship between BW and expected MU concentration to be negative but not linear, such that additional increases in BW would have diminishing effects on expected MU concentration. Results from this study indicate that the association between BW and predicted MU concentra-

Table 3. Predicted milk urea concentrations (MUN, mg/dL), calculated for different BW values, using estimates of variables that were significantly associated with milk urea and constant average values of the independent variables in the mixed effects model, for lactations $1,2,3$, and $>3$ of Holstein cows.

\begin{tabular}{lllll}
\hline & \multicolumn{4}{c}{ MUN (mg/dL) } \\
\cline { 2 - 5 } BW $(\mathrm{kg})$ & Lactation 1 & Lactation 2 & Lactation 3 & Lactation $>3$ \\
\hline 500 & 14.6 & 15.7 & 15.7 & 14.9 \\
600 & 14.3 & 15.2 & 15.1 & 14.6 \\
700 & 14.6 & 15.4 & 15.1 & 14.8 \\
\hline
\end{tabular}

tions has exponential characteristics; plotted results for each parity showed that there is a BW value at which MU concentration is minimal, so that cows weighing under or over this value have higher predicted MU concentrations. The minimal value for expected MU concentrations was reached at $600,620,650$, and $610 \mathrm{~kg}$ of BW for first-, second-, third-, and >thirdlactation cows, respectively.

At any of the considered BW, predicted MU concentrations were lower for first-lactation cows. Third- and $>$ third-lactation cows had lower predicted MU concentrations than second-lactation cows at most of the examined BW. This result agrees with previous reports by Godden et al. (2001), Johnson and Young (2003), and Hojman et al. (2004).

In the evaluated BW range, the relationship between BW and expected MU concentration was stronger for third-lactation cows, where the difference between the highest and lowest calculated MUN values was $1.2 \mathrm{mg} /$ dL. A cow weighing $600 \mathrm{~kg}$ would be expected to have a difference in MUN concentration of -1.4 to $0.6 \mathrm{mg} /$ dL compared with a cow weighing $500 \mathrm{~kg}$. A cow weighing $700 \mathrm{~kg}$ would be expected to have a difference in MUN concentration of -0.6 to $1.1 \mathrm{mg} / \mathrm{dL}$ compared with the cow weighing $600 \mathrm{~kg}$ (Table 3). Kohn et al. (2002) reported that an increase in BW from 500 to 600 $\mathrm{kg}$ is associated with a decrease of $1.2 \mathrm{mg} / \mathrm{dL}$ in MUN concentration. Results of our research highlight the significant interaction that exists between the BW-MU association and parity number.

\section{CONCLUSIONS}

In the present study, field data from 1996 cows $(25,485$ records) were used to examine the relationship 
between BW and MU concentration. A linear negative $(P<0.001)$ association was found between $\mathrm{BW}$ and $\mathrm{MU}$ concentration, which remained significant $(P<0.001)$ when the quadratic component of BW was included in the model. There was a significant interaction of the association between $\mathrm{MU}$ and BW with parity number. The resulting regression equation was used to plot predicted MU values at different BW for each parity group, using the estimates of variables having a significant association with MU and average per-lactation production values. The trends and interactions found in the present study may contribute to improving the accuracy of models designed to predict urinary nitrogen excretion rates and normative milk urea concentrations.

\section{REFERENCES}

Broderick, G. A., and M. K. Clayton. 1997. A statistical evaluation of animal and nutritional factors influencing concentrations of milk urea nitrogen. J. Dairy Sci. 80:2964-2971.

Butler, W. R., J. J. Calaman, and S. W. Beam. 1996. Plasma and milk urea nitrogen in relation to pregnancy rate in lactating dairy cattle. J. Anim. Sci. 74:858-865.

Butler, W. R., D. J. R. Cherney, and C. C. Elrod. 1995. Milk urea nitrogen (MUN) analysis: Field trial results on conception rates and dietary inputs. Page 89 in Proc. Cornell Nutr. Conf., Rochester, NY. Cornell Univ., Ithaca, NY.

Carlsson, J., J. Bergstrom, and B. Pehrson. 1995. Variations with breed, age, season, yield, stage of lactation and herd in the concentration of urea in bulk milk and individual cow's milk. Acta Vet. Scand. 35:67-77.

Coffey, M. P., G. Simm, W. G. Hill, and S. Brotherstone. 2003. Genetic evaluations of dairy bulls for daughter energy balance profiles using linear type scores and body condition score analyzed using random regression. J. Dairy Sci. 86:2205-2212.
Godden, S. M., K. D. Lissemore, D. F. Kelton, K. E. Leslie, J. S. Walton, and J. H. Lumsden. 2001. Relationships between milk urea concentrations and nutritional, management, production and economic variables in Ontario dairy herds. J. Dairy Sci. 84:1128-1139.

Hof, G., M. D. Vervoorn, P. J. Lenaers, and S. Tamminga. 1997. Milk urea nitrogen as a tool to monitor the protein nutrition of dairy cows. J. Dairy Sci. 80:3333-3340.

Hojman, D., O. Kroll, G. Adin, M. Gips, B. Tavori, and E. Ezra. 2004. Relationships between milk urea and production, nutrition and fertility traits in Israeli dairy herds. J. Dairy Sci. 87:1001-1011.

Johnson, R. G., and A. J. Young. 2003. The association between milk urea nitrogen and DHI production variables in Western commercial dairy herds. J. Dairy Sci. 86:3008-3015.

Jonker, J. S., R. A. Kohn, and R. A. Erdman. 1998. Using milk urea nitrogen to predict nitrogen excretion and utilization efficiency in lactating dairy cows. J. Dairy Sci. 81:2681-2692.

Jonker, J. S., R. A. Kohn, and R. A. Erdman. 1999. Milk urea nitrogen target concentrations for lactating dairy cows fed according to National Research Council recommendations. J. Dairy Sci. 82:1261-1273.

Kauffman, A. J., and N. R. St-Pierre. 2001. The relationship of milk urea nitrogen to urine nitrogen excretion in Holstein and Jersey cows. J. Dairy Sci. 84:2284-2294.

Kohn, R. A., K. F. Kalscheur, and E. Russek-Cohen. 2002. Evaluation of models to estimate urinary nitrogen and expected milk urea nitrogen. J. Dairy Sci. 85:227-233.

National Research Council. 1989. Pages 90-110 in Nutrient Requirements of Dairy Cattle. 6th rev. ed. Natl. Acad. Sci., Washington, DC.

Oltner, R., M. Emanuelson, and H. Wiktorsson. 1985. Urea concentrations in milk in relation to milk yield, live weight, lactation number and amount and composition of feed given to dairy cows. Livest. Prod. Sci. 12:47-57.

Rajala-Schultz, P. J., and W. J. A. Saville. 2003. Sources of variation in milk urea nitrogen in Ohio dairy herds. J. Dairy Sci. 86:1653-1661.

Rodriguez, L. A., C. C. Stallings, J. H. Herbein, and M. L. McGilliard. 1997. Effect of degradability of dietary protein and fat on ruminal, blood, and milk components of Jersey and Holstein cows. J. Dairy Sci. 80:353-363.

SAS Institute. 1999. Release 8.2. SAS Institute, Inc., Cary, NC. 